\title{
1 The role of lithic bipolar technology in Western 2 Iberia's Upper Paleolithic: the case of Vale Boi 3 (southern Portugal)
}

4 Pedro Horta* (ICArEHB, University of Algarve, Faro, Portugal) João Cascalheira (ICArEHB, University of Algarve, Faro, Portugal)

6 Nuno Bicho (ICArEHB, University of Algarve, Faro, Portugal)

7 *corresponding author | email: pedroehorta@gmail.com

\begin{abstract}
Scaled or splintered pieces are one of the most common lithic artifacts type in Upper Paleolithic assemblages throughout Europe, especially in its westernmost regions. Despite this, and even after one century of being identified there is still no consensus on how to define, analyze or interpret these tools. In western Iberia, there is a clear lack of comprehensive studies regarding this type of artifacts at a regional scale. In this paper, we present a first techno-morphological analysis of a sample of scaled pieces from the Upper Paleolithic site of Vale Boi. Our first aim was to build upon existing analytical models in order to identify function and possible reduction strategies for these artifacts. Our second goal was to critically evaluate the role of these artifacts within western Iberia's Upper Paleolithic. Our results showed that functional identification of scaled pieces is still not clear. By comparing our data with other author's we found that current models could not be applied to the archaeological record, as the attribute variability is too high. Furthermore, in this region, we found that higher frequencies of bipolar technology can be found related to residential sites due to both functional and cultural patterns. While we still cannot define a specific function for these artifacts (intermediate pieces or wedges for working hard raw materials or cores for the extraction of chips and small bladelets), it is clear that they had a major role in the variability and intensification of resource exploitation during the Upper Paleolithic in western Iberia.
\end{abstract}

\section{Keywords}

Stone tools; Bipolar technology; Upper Paleolithic; Western Europe

\section{Introduction}

Bipolar technology is generically classified into two types of lithic artifacts - bipolar cores and scaled pieces (also known as splintered pieces or pièce esquilée), this latter being the main focus of this paper. Their distinction, however, has not always been consensual (Hayden 1980). Besides the fact that bipolar cores are often confused or lumped with scaled pieces (de la Peña 2011; Villa et al. 2018), the definition of scaled piece has suffered significant changes ever since 
its initial identification in the early 20th century and, to this day, there still seems to be no worldwide accepted clear definition for this type of artifact. The first definition of scaled pieces was proposed by Bardon and Bouyssonie (1906), describing them as a result of bipolar knapping through direct percussion, with the "core" resting on a hard surface, originating splintering in both ends of the tool. Since then, several other definitions were adopted and adapted by researchers for a very diverse set of contexts across the world (e.g. Hayden 1980; MacDonald 1985; Octobon 1938; Shott 1989; Sonneville-Bordes and Perrot 1956).

Beyond the classification debate, the biggest issue with this type of tools comes from a functional standpoint, a problem that has also been largely debated (e.g. Binford and Quimby 1963; de la Peña 2011; Flood 1980; Igreja and Porraz 2013; LeBlanc 1992; Lucas and Hays 2004; Shott 1999; Tixier 1963). The issue surrounding this problem lies within the functional equifinality of these artifacts. Contrary to bipolar cores, that are exclusively part of a technological reduction sequence with the goal of blank extraction (e.g. Binford and Quimby 1963; Crabtree 1972; Leaf 1979), scaled pieces have been associated with two distinct types of activities: (1) as intermediate pieces or wedges for working hard organic raw materials (e.g. bone, ivory, antler); and (2) as cores for the extraction of chips, small flakes and bladelets (Brantingham et al. 2004). Although largely debated, the ambiguity of this classification has, however, been ignored in some of the most recent literature, with some authors not acknowledging that bipolar evidence in stone tools might also result from other activities other than only reduction strategies (see e.g. Hiscock 2015).

Many current studies on scaled pieces apply use-wear methods (e.g. Bader et al. 2015; de la Peña 2011, 2015a, 2015b; de la Peña and Wadley 2014; Gibaja et al. 2007; Igreja and Porraz 2013; Lucas and Hays 2004; Sano 2012), focusing on the identification of polishes and use-wear patterned stigmas, through both micro and macroscopic analysis of splintered surfaces and its comparison with experimental assemblages. Frequently, these studies coincide in interpreting scaled pieces as intermediate elements for the work of hard organic raw materials. The study by P. de la Peña $(2011,2015 b)$ is one of the most recent and relevant references in this regard. The author presents the results of an experimental program aiming to identify specific wear patterns in the use of bipolar techniques that allow the distinction between different types of activities and worked materials. Results indicate that while no visible differences can be identified in the percussion area, significant variation can be observed in the morphology of the areas in contact with the worked material.

As in many other regions and Stone Age periods across the world (e.g. Diez-Martín et al. 2009; Igreja and Porraz 2013; Langejans 2012; White 1968), evidence of bipolar technologies are quite ubiquitous in European Upper Paleolithic contexts. In many sites, bipolar elements classified as scaled pieces have been associated with different functionalities (see e.g. de la Peña 2011; Sano 2012; Zilhão 1997).

In the case of the westernmost regions of Iberia, scaled pieces are commonly found in archaeological contexts ranging from the Upper Paleolithic to the Neolithic (e.g. Bicho 2000; Carvalho 1998; Zilhão 1997). While scarce, the majority of Portuguese Paleolithic studies (e.g. Almeida 2000; Gonçalves 2012) have not presented, so far, any context-specific interpretations for the presence of scaled pieces. Most references broadly interpret these as bipolar cores for the extraction of small flakes, bladelets and chips to be used in composite tools (e.g. Zilhão 1997), or as intermediate pieces for working hard materials (Gibaja et al. 2007; Marreiros 2009). Zilhão 
(1997), for example, argues that the presence of scaled pieces throughout the Upper Paleolithic sequence of central Portugal is inversely proportional to the presence of "carinated cores", and thus it is likely that the former should have worked as a flexible substitute for the latter. Carvalho (1998) agrees with this interpretation and considers it also valid for the Portuguese early Neolithic.

While we agree that some of the elements might have been used as cores, these interpretations seem simplistic, and those studies seem to have little to no analytical evidence to back those hypotheses, other than the inverse relationship mentioned above. This results, in part, from the lack of comprehensive studies regarding this type of artifacts at a regional scale. Additionally, the contexts from where most of these artifacts were recovered did not have good organic preservation or dedicated use-wear studies and, thus, no direct association between these tools and the exploitation of hard organic raw materials is possible, and, in face of the nonexistence of any absolute dates, their precise chronological attribution is also, frequently, unreliable.

In this paper, we present a first approach to the characterization of the morpho-technological variability and consequent role of scaled pieces during the Upper Paleolithic of the westernmost regions of Iberia (c. 32-10 ka cal BP). Using data from the multi-component, thoroughly dated, site of Vale Boi, located in southern Portugal, we present the analysis of a series of technological and morpho-functional attributes of a relatively large set of scaled pieces coming from one of the areas of the site. Using these data as a starting point, we then explore the relationship between the variability detected in the production and use of these artifacts with inter-site lithic technological patterns, and with the striking evidence for an intensification and diversification of faunal resources exploitation during the time-span under consideration.

\section{Vale Boi}

The archaeological site of Vale Boi is located in the western edge of the Algarve region (southern Portugal) (Figure 1). The site can be found in a small valley following a river northsouth for $2 \mathrm{~km}$ until it reaches the Atlantic Ocean. Archaeological deposits occupy an estimated area of over $10000 \mathrm{sq}$. meters across a stepped slope marked at the top by a 10 meter-high limestone cliff face (Bicho et al. 2012, 2010).

A rather complete Upper Paleolithic sequence has been identified at Vale Boi, with all the traditionally-defined techno-complexes (Gravettian, Proto-Solutrean, Solutrean and Magdalenian) being identified across the three main excavation areas: the Terrace, the Rockshelter, and the Slope.

The Terrace area is located in the lower part of the hill. In this area, the longest archaeological sequence of the site can be found, including the complete Upper Paleolithic sequence but also three Holocene horizons, corresponding to Neolithic, Mesolithic and Epipaleolithic occupations (Bicho et al. 2012; Cascalheira et al. 2017). From within the lower levels of this area, an Early Gravettian occupation was discovered, dated to c. $32 \mathrm{ka}$ cal BP, being one of the earliest radiocarbon dates for anatomically modern humans in Southern Iberia (Bicho et al. 2013; Marreiros et al. 2015).

The Rockshelter area is a collapsed rock shelter located in the upper part of the slope, a couple of meters below the limestone cliff. This collapse would have occurred after the Last Glacial 
Maximum, since below the collapsed debris, several Solutrean occupations can be found, overlaying a sequence of very ephemeral Gravettian horizons (Cascalheira et al. 2012; Manne et al. 2012; Marreiros 2009). The Solutrean is dated to between c. $20 \mathrm{ka}$ and $25 \mathrm{ka}$ cal BP (Cascalheira and Bicho 2015), while the Gravettian is dated between $26 \mathrm{ka}$ and $32 \mathrm{ka}$ cal BP (Marreiros et al. 2015).

Finally, the Slope section, from where the assemblage here presented is coming from, is composed of a series of excavation areas opened across the mid-hill sector of the site. These areas exhibit heterogeneous conditions in terms of site formation processes and archaeological preservation (Manne et al. 2012), but all revealed the presence of occupations attributed to the Gravettian, Proto-Solutrean, Solutrean and Magdalenian. Like in the previous areas, remains are well preserved, and high frequencies of lithic artifacts, malacological and mammalogical fauna and bone tools were recovered. No habitation features were identified in this area and based on the conditions and type of artifacts found, it has been suggested that this area would have mostly functioned as a midden deposit (Bicho et al. 2012, 2010).
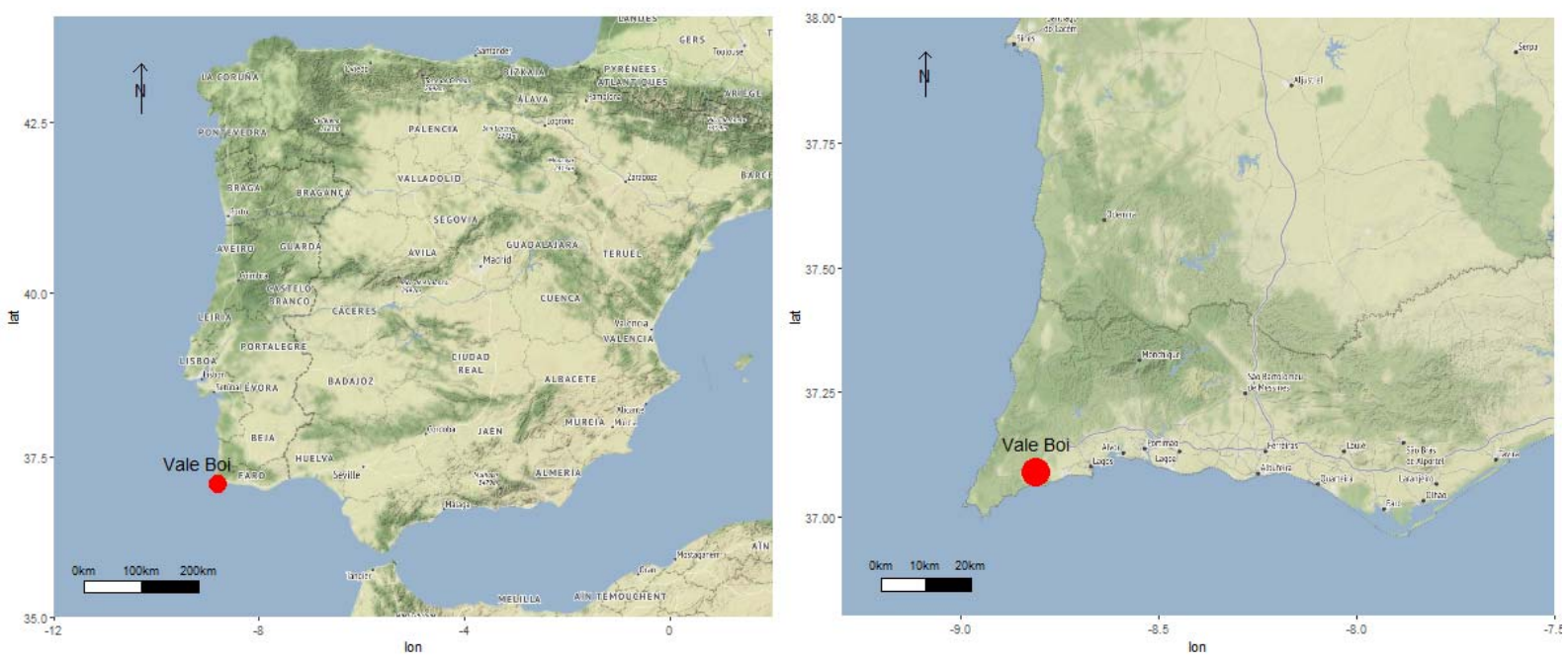

Figure 1 Location of the site of Vale Boi. Map data are from Stamenmap (http://maps.stamen.com), using the ggmap package Kahle and Wickham (2013).

Lithic technology

Vale Boi's lithic studies have revealed a general tendency for stable technological and functional patterns throughout the Upper Paleolithic (e.g. Bicho et al. 2012; Bradtmöller et al. 2016; Cascalheira 2013; Cascalheira et al. 2017, 2012; Gibaja and Bicho 2011; Marreiros and Bicho 2013; Marreiros et al. 2015, 2018; Marreiros 2009). This can be explained, partially, by raw material availability. Most raw materials were procured locally, or regionally from deposits located at no more than $20 \mathrm{~km}$ away from the site (Bicho et al. 2010). Chert was the most used rock type for more complex retouched tools production, while quartz and greywacke were mostly used for flake extraction and simple retouched tools production. Other raw materials can 
be found at the site, but much more restricted, both diachronically and functionally, within each techno-complex. Schist, for instance, shows up in some occupations almost exclusively connected to mobile art. Dolerite is only found in the Proto-Solutrean levels (Belmiro et al. 2017), while chalcedony is mostly limited to the Proto-Solutrean and Solutrean levels (Cascalheira et al. 2012).

Chert is the most abundant knapped rock type in Vale Boi. Throughout the several occupations, chert was considered the preferred rock type for knapping, which is evident by the way it was explored with much more complex strategies than either greywacke or quartz. While it can be said that chert exploration strategies were more elaborate, the most common strategies were still simple unidirectional or bidirectional reduction sequences, producing mostly flakes (Marreiros et al. 2012). Elongated products are found at low frequencies across all chronologies. When present, retouched tools are mostly notches, denticulates, end-scrapers, and, although not retouched artifacts per se, scaled pieces. One possible reason for these simplistic strategies seems to be an overall low knapping quality, since nodules are quite small, and frequently show a high degree of tectonically derived fractures (Pereira et al. 2016).

Two distinct types of quartz were identified at the site. The first is a thick grain, low-quality type, mostly inadequate for knapping. Still, this kind of quartz is present in large quantities and is most likely associated with stone boiling and grease rendering activities (Bicho et al. 2012; Manne 2010, 2014; Manne and Bicho 2009; Manne et al. 2012). The second type of quartz is characterized by finer-grain small pebbles with yellowish cortex. This type of quartz was knapped using rather simple strategies, mostly for small flake production, which in turn were used to produce simple and versatile tools.

Greywacke is the third most frequent raw material at Vale Boi, showing up in the site mostly in the form of large slabs, in which the identification of concavely shaped impact marks is thought to result from their use as anvils. The importance of greywacke anvils is indicated by its high frequency, with hundreds of slabs found in many levels throughout all occupations (Bicho et al. 2012; Manne et al. 2012). Greywacke was also knapped for flake extraction, using expedient unidirectional reduction strategies (Cascalheira 2013; Marreiros 2009).

\section{$\underline{\text { Subsistence patterns }}$}

Organic preservation is fairly good at Vale Boi. Faunal remains can be frequently found in all occupations, both of terrestrial and marine resources. Marine fauna at the site is marked by the presence of mollusks, crustaceans, some fish vertebrae and, in rare occasions, marine mammal remains (Manne 2010). Regarding terrestrial fauna, three species dominate the vertebrate group: rabbit (Oryctolagus cuniculus), red deer (Cervus elaphus) and horse (Equus caballus). Smaller amounts of wild ass (Equus hydruntinus), aurochs (Bos primigenius), ibex (Capra pyrenaica) and wild boar (Sus scrofa) are also present (Manne 2010, 2014; Manne et al. 2012). One of the most interesting patterns within the faunal assemblages is that a large portion of ungulate remains present specific types of fracture that have been associated with bone marrow extraction activities. Red deer and horse remains frequently show evidence of opposed cone fractures, trituration and smashing (Manne 2010, 2014; Manne and Bicho 2009; Manne et al. 2012).

Ungulates would have been hunted and processed in a similar fashion throughout the Upper Paleolithic. While there were conditions for the whole bones to be preserved, these bones are 
frequently anthropically broken. These fragmentation patterns seem to be linked to grease rendering activities (Manne 2010, 2014; Manne et al. 2012). The main goal of grease rendering is to obtain grease, through heat exposure from animal bones, as it has a very high caloric value. Other than this, this grease could have many uses with the addition of being easily stored and transported (Manne et al. 2012). The spongeous bone parts would be fragmented and deposited in a hole, covered with animal pelts full of water, after which, pre-heated rock fragments were added. The high temperature of the rocks would make the water boil and therefore separate the grease from the spongeous bones creating a highly nutritional stew. After being cooled the grease would accumulate at the top where it could be easily removed, transported and stored. Unlike simple bone marrow extraction, this method involved large preparation, including water transport, fire, and heat production, rock heating, and finally the storing of the grease (Manne 2014).

These grease rendering techniques are thought to be quite common at the site since the parts of the bones with higher amounts of fat are missing despite the good preservation of the rest of the remains. Fragmented ungulate remains show up in the site connected to large amounts of thermo-altered quartz, anvils, hard hammers and scaled pieces. This suggests that red deer and horse bones were processed and afterward intensively grease rendered. To confirm this, a single scaled piece was found stuck to a cracked phalanx in a Gravettian horizon (Manne 2010, 2014; Manne and Bicho 2009; Manne et al. 2012).

\section{Methods}

\section{$\underline{\text { Scaled pieces attribute analysis }}$}

Based on previous works (e.g. Hayden 1980) here we define scaled pieces as artifacts of variable size and morphology, showing traces of crushing and splintering of edges at opposite ends, caused by direct percussion at one end, and subsequent crushing of the other for being rested on a hard surface. Scaled pieces present always two opposite surfaces, just like a flake or blade would, but at least one of them shows signs of crushing. Crushing traces can be bifacially or unifacially distributed. Some scaled pieces do not present crushing in opposed platforms, but are still classified as scaled pieces here. This detail has been previously referred by Villa et al. (2018) who noted that some edges may present a flat (instead of intensively shattered) platform. Our criteria does not include a particular type of blank because, as we will show in later sections of the paper, these artifacts can originate from flakes, blades or debris.

On the contrary, following mostly Hayden (1980) and Leaf (1979), bipolar cores are not marked by bifacially opposed surfaces. Their shape is more blocky and angular, showing evidence of, at least, one flaking surface with two opposed platforms (the striking platform and the base) with typical crushing and flake removal on one or both ends. The striking platform is the surface that is struck with a hammerstone to produce blanks. Typically, it exhibits little crushing except near the point of impact. Large flake scars tend to originate at the striking platform. The base is the surface that rests on the anvil, from where small flake scars can also originate.

All lithic artifacts recovered from the Slope area of Vale Boi that fit the scaled piece definition presented above were considered for this study, independent of raw material or technological class. 
229 Attribute analysis was split into two main groups, each corresponding to two distinct types of features: (1) technological attributes (Table 1) and (2) morpho-functional attributes (Table 2). In the first group, a series of variables traditionally used in lithic studies (e.g. Andrefsky Jr 2005; Inizan et al. 1999) were recorded, aiming to characterize patterns of blank choice for the application of bipolar technology. For the second group of variables, a macroscopic approach building upon the work of de la Peña (2011) and Fischer et. al (1984) was adopted. Studies by Sano (2012), and Gibaja et al. (2007) indicate that, since use-wear traces are formed before the splintering, the removal of small chips removes most of the polishes and use-wear traces left by the contact with the static element (either a stone anvil or hard-organic materials). This, together with the large presence of quartz artifacts in our sample, prevented us to pursue a microscopic use-wear approach for this study in particular.

Table 1 Technological attributes used for the analysis of scaled pieces included in this study.

\begin{tabular}{|c|c|c|c|}
\hline Variable & $\begin{array}{l}\text { Variable name in } \\
\text { database }\end{array}$ & Values & Observations \\
\hline \multirow[t]{5}{*}{ Raw Material } & RawMaterial & Quartz & \\
\hline & & Chert & \\
\hline & & Greywacke & \\
\hline & & Chalcedony & \\
\hline & & Others & \\
\hline \multirow[t]{9}{*}{ Type of blank } & Blank & Blade & \\
\hline & & BladeFragment & \\
\hline & & Bladelet & \\
\hline & & BladeletFragment & \\
\hline & & Core & \\
\hline & & Flake & \\
\hline & & FlakeFragment & \\
\hline & & Nodule & \\
\hline & & Non_Identifiable & \\
\hline $\begin{array}{l}\text { Length of the } \\
\text { typological axis }\end{array}$ & TypologicalAxisLength & $\mathrm{mm}$ & $\begin{array}{l}\text { Typological axis is defined as a vector that } \\
\text { proceeds perpendicular to the two opposed } \\
\text { damaged platforms, bisecting them }\end{array}$ \\
\hline $\begin{array}{l}\text { Length of the } \\
\text { technological axis }\end{array}$ & TechnologicalAxisLength & $\mathrm{mm}$ & $\begin{array}{l}\text { Same as axis of flaking in Debénath and } \\
\text { Dibble (1994) }\end{array}$ \\
\hline $\begin{array}{l}\text { Width of the } \\
\text { typological axis }\end{array}$ & TypologicalAxisWidth & $\mathrm{mm}$ & $\begin{array}{l}\text { Distance at a mid-point between two edges } \\
\text { of the artifact, as measured perpendicularly } \\
\text { to the typological length }\end{array}$ \\
\hline $\begin{array}{l}\text { Width of the } \\
\text { technological axis }\end{array}$ & TechnologicalAxisWidth & $\mathrm{mm}$ & $\begin{array}{l}\text { Distance at a mid-point between two edges } \\
\text { of the artifact, as measured perpendicularly } \\
\text { to the technological length }\end{array}$ \\
\hline Thickness & Thickness & $\mathrm{mm}$ & $\begin{array}{l}\text { Measured at the intersection of the } \\
\text { typological length and width }\end{array}$ \\
\hline Axes coincidence & AxisCoincident & Yes & $\begin{array}{l}\text { Coincidence between the typological and } \\
\text { technological axes }\end{array}$ \\
\hline Retouch presence & Retouch & Absent & Presence of retouch in artifact's edges \\
\hline
\end{tabular}




\begin{tabular}{|c|c|c|c|}
\hline & & Present & \\
\hline \multirow{5}{*}{$\begin{array}{l}\text { Percentage of } \\
\text { cortex }\end{array}$} & Cortex & No_Cortex & \\
\hline & & $>25 \%$ & \\
\hline & & $25-50 \%$ & \\
\hline & & $50-95 \%$ & \\
\hline & & $>95 \%$ & \\
\hline \multirow[t]{6}{*}{ Platform type } & Butt & Absent & $\begin{array}{l}\text { See Inizan et al (1999) for description of } \\
\text { each value }\end{array}$ \\
\hline & & Cortical & \\
\hline & & Dihedral & \\
\hline & & Faceted & \\
\hline & & Pointed & \\
\hline & & Flat & \\
\hline \multirow[t]{4}{*}{ Profile } & Profile & Straight & \\
\hline & & Curved & \\
\hline & & Irregular & \\
\hline & & Twisted & \\
\hline \multirow{5}{*}{$\begin{array}{l}\text { Cross-section } \\
\text { morphology }\end{array}$} & CrossSection & Other & \\
\hline & & Irregular & \\
\hline & & Rectangular & \\
\hline & & Trapezoidal & \\
\hline & & Triangular & \\
\hline \multirow{7}{*}{$\begin{array}{l}\text { Longitudinal } \\
\text { section } \\
\text { morphology }\end{array}$} & SideSection & Elliptical & \\
\hline & & Irregular & \\
\hline & & Other & \\
\hline & & Rectangular & \\
\hline & & Semicircular & \\
\hline & & Trapezoidal & \\
\hline & & Triangular & \\
\hline \multirow{7}{*}{$\begin{array}{l}\text { Blank edge } \\
\text { morphology }\end{array}$} & BlankShape & Biconvex & \\
\hline & & Circular & \\
\hline & & Converging & \\
\hline & & Diverging & \\
\hline & & Irregular & \\
\hline & & Others & \\
\hline & & Parallel & \\
\hline \multirow[t]{2}{*}{$\begin{array}{l}\text { Scar dorsal } \\
\text { pattern }\end{array}$} & DorsalScars & $\begin{array}{l}\text { Bidirectional- } \\
\text { Alternating }\end{array}$ & \\
\hline & & Bidirectional- & \\
\hline
\end{tabular}


Parallel

Bidirectional-

Perpendicular

Non_Identifiable

Parallel-Distal

Parallel-Proximal

Parallel-One-Side

Radial

Other

Fire traces $\quad$ Fire Burnt

No_traces

Thermal-Treatment

Table 2 Morpho-functional attributes used for the analysis of each damaged platform of scaled pieces included in this study. *Adapted from Gonzalez-Urquijo and Ibanez-Estévez (1994). **Adapted from de la Peña (2011).

\begin{tabular}{|c|c|c|c|}
\hline Variable & $\begin{array}{l}\text { Variable name in } \\
\text { database }\end{array}$ & Values & Observations \\
\hline \multirow{4}{*}{$\begin{array}{l}\text { Number of damaged } \\
\text { platforms }\end{array}$} & DamagePlatforms & 1 & \\
\hline & & 2 & \\
\hline & & 3 & \\
\hline & & 4_or_more & \\
\hline Platform Width & Width & $\mathrm{mm}$ & \\
\hline Number of scars & NScars & $\mathrm{N}$ & \\
\hline \multirow[t]{3}{*}{ Platform Angle } & Angle & $<45^{\circ}$ & \\
\hline & & $>45^{\circ}$ & \\
\hline & & Platform & $>90^{\circ}$ angle \\
\hline \multirow[t]{6}{*}{ Platform Delineation* } & ScarEdgeDelineation & Concave & \\
\hline & & Convex & \\
\hline & & Irregular & \\
\hline & & Oblique & \\
\hline & & Pointed & \\
\hline & & Straight & \\
\hline \multirow[t]{3}{*}{ Degree of damage** } & DamageDegree & High & No traces of the original platform are visible \\
\hline & & Medium & $\begin{array}{l}\text { Some traces of the original platform are } \\
\text { visible }\end{array}$ \\
\hline & & Low & Original platform is visible \\
\hline \multirow[t]{5}{*}{ Scar Shape** } & ScarShape & Half-Moon & \\
\hline & & Irregular & \\
\hline & & Mixed & \\
\hline & & Quadrangular & \\
\hline & & Semicircular & \\
\hline
\end{tabular}




\begin{tabular}{|c|c|c|c|}
\hline \multirow{4}{*}{ Scar Distribution* } & \multirow{4}{*}{ ScarDistribution } & \multicolumn{2}{|l|}{ Trapezoidal } \\
\hline & & \multicolumn{2}{|l|}{ Triangular } \\
\hline & & Central & $\begin{array}{l}\text { Scars are limited to the central area of the } \\
\text { platform }\end{array}$ \\
\hline & & Lateral & $\begin{array}{l}\text { Scars are limited to one of the sides of the } \\
\text { platform }\end{array}$ \\
\hline \multirow{4}{*}{ Scar Disposition* } & \multirow{3}{*}{ ScarArrangement } & Total & Scars completely cover the platform \\
\hline & & Aligned & $\begin{array}{l}\text { Scars are parallel and next to each other } \\
\text { without overlapping }\end{array}$ \\
\hline & & Isolated & Scars are isolated \\
\hline & \multirow[b]{2}{*}{ ScarExtension } & Overlapped & Scars overlap \\
\hline \multirow[t]{3}{*}{ Scar Extension** } & & Invasive & $\begin{array}{l}\text { Scars extent to a maximum of } 49 \% \text { of the } \\
\text { typological axis length }\end{array}$ \\
\hline & \multirow{4}{*}{ ScarFacialDistribution } & Marginal & $\begin{array}{l}\text { Scars extent to a maximum of } 20 \% \text { of the } \\
\text { typological axis length }\end{array}$ \\
\hline & & Mixed & Scar extension is both invasive and marginal \\
\hline \multirow[t]{2}{*}{$\begin{array}{l}\text { Scar Facial } \\
\text { Distribution** }\end{array}$} & & Bifacial & $\begin{array}{l}\text { Scars are present in both faces of the } \\
\text { platform }\end{array}$ \\
\hline & & Unifacial & $\begin{array}{l}\text { Scars are present in only one face of the } \\
\text { platform }\end{array}$ \\
\hline
\end{tabular}

247 Macroscopic morpho-functional attributes were separately analyzed for each damaged platform, 248 aiming to detect patterns of morphological change that occurred in artifacts during use.

249 Following the work of de la Peña $(2011,2015 b)$ and Gonzalez-Urquijo and Ibanez-Estévez 250 (1994), we expected that these attributes would be indicative of which function the artifacts had. 251 For instance, according to de la Peña $(2011,2015$ b), for pieces used as wedges, the delineation of 252 the damaged platforms are constantly asymmetrical and only the hammered edge clearly shows 253 the typical écaille retouch. Furthermore, these pieces would have irregular shapes, variable scar 254 size, and irregular scar distribution. On the other hand, pieces used as bipolar cores would have 255 squared or rectangular shapes, symmetric straight damaged platforms, and a higher frequency of scars on the hammered edge than on the opposed edge. The addition of other attributes drawing upon the work by Gonzalez-Urquijo and Ibanez-Estévez (1994) was made following the same reasoning. We expected, thus, to be able to differentiate pieces used as wedges from pieces used as cores, as both groups would show distinct combinations of attributes. To assist us with this differentiation we tested the presence of the referred patterns within our assemblage using descriptive and multivariate statistical analysis and comparing it with the data described by the referred authors.

\section{Analysis, reproducibility and open source materials}

264 All analyses and data processing were accomplished in R (version 3.5.1) ( $R$ 2013). Following recent concerns on the reproducibility of archaeological analysis, we include the entire $\mathrm{R}$ code used for all the analysis and visualizations contained in this paper in our online research compendium at https://dx.doi.org/10.17605/OSF.IO/WPXGH. To produce those files we followed the procedures described by Marwick et al. (2017) for the creation of research compendiums to enhance the reproducibility of research. The files provided contain all the raw 
data used in our analysis as well as a custom R package (Wickham 2015) holding the code used for all analysis and to produce all tables and figures. To enable maximum re-use, our code is released under the MIT license, our data as CC-0, and our figures as CC-BY, (for more information see Marwick 2016).

\section{Results}

A total of 139 scaled pieces were analyzed, of which $42.45 \%$ come from Gravettian, and $45.32 \%$ from Solutrean levels, as shown in Table (3). In terms of raw materials, the great majority of pieces were either made on quartz or chert, with chalcedony being represented only by 5 artifacts.

\section{Table 3 Frequencies of scaled pieces used in this study, by raw material and chronological period. Percentages} are shown in parentheses.

\begin{tabular}{lllll} 
& Chert & Quartz & Chalcedony & Total \\
\hline Gravettian & $20(32.8)$ & $39(53.4)$ & $0(0.0)$ & $59(42.4)$ \\
Proto-Solutrean & $6(9.8)$ & $4(5.5)$ & $1(20.0)$ & $11(7.9)$ \\
Solutrean & $32(52.5)$ & $27(37.0)$ & $4(80.0)$ & $63(45.3)$ \\
Magdalenian & $3(4.9)$ & $3(4.1)$ & $0(0.0)$ & $6(4.3)$
\end{tabular}

As previously mentioned, concerning technological data, one of our main objectives was to characterize the choice of blanks involved in bipolar technology. Overall, the technological analysis revealed some trends that lasted throughout the Upper Paleolithic, in agreement with the general patterns of lithic technology recorded for the site. Across all techno-complexes, blanks used were either flakes (based on the recognition of dorsal and ventral surfaces) or unclassifiable fragments, but the choice seems to be different for each raw material. For quartz, in the Gravettian assemblage, the blank types are almost equally split between flakes and unclassifiable pieces (Table 4). In other periods, flakes were the preferred type of blank (Tables 6, 5 and 7). Regarding chert, in every occupation flakes dominate the assemblages, followed by a reduced number $(\mathrm{n}=12)$ of unclassifiable blanks. The small sample of chalcedony blanks is exclusively represented by flakes.

Technological and morphological characteristics of the flake blanks present very similar patterns across time and among raw materials. The blanks sought after would have straight profiles, parallel edges, no cortical surfaces, and trapezoidal or triangular shaped cross-sections.

Other characteristics of the assemblage are the low frequency of retouch found in the nondamaged edges $(n=2)$, fire alterations $(n=4)$, and the presence of original striking platforms ( $n$ $=8$ ). Still, when present, retouch is located in the lateral part of the artifacts, similar to what would define a side-scraper. In a very small number of cases, when striking platforms are present, these are mostly flat. The absence of the original blank platforms is to be expected in this type of artifact, mostly due to the functional use of the pieces, and consequent removal of the platform, rather than an actual choice. The large absence of platforms may, also, be the result of the use of the technological axis as the main functional axis. In fact, when identifiable, 
technological and typological axes coincide in $50.5 \%$ of the cases. The longitudinal sections show a large variability of shapes, independent of raw materials or chronologies. Similarly, the dorsal pattern of previous removals was rarely identified, although this, like with the case of platform absence, might occur due to the functional stigmas and be dependent on the intensity of use for each artifact.

Table 4 Technological attributes frequencies by raw materials for the Gravettian sample. Percentages are shown in parentheses.

\begin{tabular}{|c|c|c|c|}
\hline & Chert & Quartz & Total \\
\hline \multicolumn{4}{|l|}{ Blank } \\
\hline CompleteFlake & $6(33.3)$ & $7(30.4)$ & $13(31.7)$ \\
\hline FlakeFragment & $12(66.7)$ & $15(65.2)$ & 27 (65.9) \\
\hline Non_identifiable & $0(0.0)$ & $1(4.3)$ & $1(2.4)$ \\
\hline \multicolumn{4}{|l|}{ AxisCoincident } \\
\hline No & $9(50.0)$ & $7(30.4)$ & $16(39.0)$ \\
\hline Yes & $9(50.0)$ & $16(69.6)$ & $25(61.0)$ \\
\hline \multicolumn{4}{|l|}{ CrossSection } \\
\hline Other & $0(0.0)$ & $0(0.0)$ & $0(0.0)$ \\
\hline Rectangular & $1(5.6)$ & $3(13.0)$ & $4(9.8)$ \\
\hline Trapezoidal & $10(55.6)$ & $15(65.2)$ & $25(61.0)$ \\
\hline Triangular & 7 (38.9) & $5(21.7)$ & $12(29.3)$ \\
\hline \multicolumn{4}{|l|}{ SideSection } \\
\hline Elliptical & $4(22.2)$ & $5(21.7)$ & $9(22.0)$ \\
\hline Irregular & $1(5.6)$ & $1(4.3)$ & $2(4.9)$ \\
\hline Other & $2(11.1)$ & $0(0.0)$ & $2(4.9)$ \\
\hline Rectangular & $1(5.6)$ & $0(0.0)$ & $1(2.4)$ \\
\hline Semi_Circular & $1(5.6)$ & $6(26.1)$ & $7(17.1)$ \\
\hline Trapezoidal & $8(44.4)$ & $7(30.4)$ & 15 (36.6) \\
\hline Triangular & $1(5.6)$ & $4(17.4)$ & $5(12.2)$ \\
\hline \multicolumn{4}{|l|}{ Profile } \\
\hline Curved & $2(11.1)$ & $0(0.0)$ & $2(4.9)$ \\
\hline Straight & $16(88.9)$ & $23(100.0)$ & $39(95.1)$ \\
\hline \multicolumn{4}{|l|}{ BlankShape } \\
\hline Biconvex & $0(0.0)$ & $2(8.7)$ & $2(4.9)$ \\
\hline Circular & $2(11.1)$ & $2(8.7)$ & $4(9.8)$ \\
\hline Converging & $0(0.0)$ & $0(0.0)$ & $0(0.0)$ \\
\hline Irregular & $2(11.1)$ & $2(8.7)$ & $4(9.8)$ \\
\hline Other & $1(5.6)$ & $1(4.3)$ & $2(4.9)$ \\
\hline Parallel & $13(72.2)$ & $16(69.6)$ & $29(70.7)$ \\
\hline \multicolumn{4}{|l|}{ Cortex } \\
\hline$<25 \%$ & $2(11.1)$ & $1(4.3)$ & $3(7.3)$ \\
\hline$>95 \%$ & $0(0.0)$ & $1(4.3)$ & $1(2.4)$ \\
\hline
\end{tabular}




$\begin{array}{llll}25-50 \% & 2(11.1) & 0(0.0) & 2(4.9) \\ 50-95 \% & 2(11.1) & 0(0.0) & 2(4.9) \\ \begin{array}{l}\text { No_Cortex } \\ \text { ButtType }\end{array} & 12(66.7) & 21(91.3) & 33(80.5) \\ \text { Absent } & 14(77.8) & 23(100.0) & 37(90.2) \\ \text { Flat } & 4(22.2) & 0(0.0) & 4(9.8) \\ \text { Retouch } & & & \\ \text { No } & 17(94.4) & 23(100.0) & 40(97.6) \\ \text { Yes } & 1(5.6) & 0(0.0) & 1(2.4) \\ \text { Fire } & & & \\ \text { Burnt } & 1(5.6) & 0(0.0) & 1(2.4) \\ \text { No_Traces } & 17(94.4) & 23(100.0) & 40(97.6)\end{array}$

314 Table 5 Technological attributes frequencies by raw materials for the Proto-Solutrean sample. Percentages are shown in parentheses.

\begin{tabular}{|c|c|c|c|c|}
\hline & Chert & Quartz & Chalcedony & Total \\
\hline \multicolumn{5}{|l|}{ Blank } \\
\hline CompleteFlake & $3(60.0)$ & $2(50.0)$ & $0(0.0)$ & $5(50.0)$ \\
\hline FlakeFragment & $2(40.0)$ & $2(50.0)$ & $1(100.0)$ & $5(50.0)$ \\
\hline Non_identifiable & $0(0.0)$ & $0(0.0)$ & $0(0.0)$ & $0(0.0)$ \\
\hline \multicolumn{5}{|l|}{ AxisCoincident } \\
\hline No & $3(60.0)$ & $1(25.0)$ & $1(100.0)$ & $5(50.0)$ \\
\hline Yes & $2(40.0)$ & $3(75.0)$ & $0(0.0)$ & $5(50.0)$ \\
\hline \multicolumn{5}{|l|}{ CrossSection } \\
\hline Other & $1(20.0)$ & $0(0.0)$ & $0(0.0)$ & $1(10.0)$ \\
\hline Trapezoidal & $4(80.0)$ & $4(100.0)$ & $1(100.0)$ & $9(90.0)$ \\
\hline Triangular & $0(0.0)$ & $0(0.0)$ & $0(0.0)$ & $0(0.0)$ \\
\hline \multicolumn{5}{|l|}{ SideSection } \\
\hline Semi_Circular & $0(0.0)$ & $1(25.0)$ & $0(0.0)$ & $1(10.0)$ \\
\hline Trapezoidal & $5(100.0)$ & $2(50.0)$ & $1(100.0)$ & $8(80.0)$ \\
\hline Triangular & $0(0.0)$ & $1(25.0)$ & $0(0.0)$ & $1(10.0)$ \\
\hline \multicolumn{5}{|l|}{ Profile } \\
\hline Straight & $5(100.0)$ & $4(100.0)$ & $1(100.0)$ & $10(100.0)$ \\
\hline \multicolumn{5}{|l|}{ BlankShape } \\
\hline Circular & $1(20.0)$ & $0(0.0)$ & $0(0.0)$ & $1(10.0)$ \\
\hline Irregular & $1(20.0)$ & $1(25.0)$ & $1(100.0)$ & $3(30.0)$ \\
\hline Other & $1(20.0)$ & $0(0.0)$ & $0(0.0)$ & $1(10.0)$ \\
\hline Parallel & $2(40.0)$ & $3(75.0)$ & $0(0.0)$ & $5(50.0)$ \\
\hline \multicolumn{5}{|l|}{ Cortex } \\
\hline$<25 \%$ & $1(20.0)$ & $0(0.0)$ & $0(0.0)$ & $1(10.0)$ \\
\hline No_Cortex & $4(80.0)$ & $4(100.0)$ & $1(100.0)$ & $9(90.0)$ \\
\hline ButtType & & & & \\
\hline
\end{tabular}




$\begin{array}{lllll}\text { Absent } & 5(100.0) & 3(75.0) & 1(100.0) & 9(90.0) \\ \text { Flat } & 0(0.0) & 1(25.0) & 0(0.0) & 1(10.0) \\ \begin{array}{l}\text { Retouch } \\ \text { No }\end{array} & 5(100.0) & 4(100.0) & 1(100.0) & 10(100.0) \\ \begin{array}{l}\text { Fire } \\ \text { No_Traces }\end{array} & 5(100.0) & 4(100.0) & 1(100.0) & 10(100.0)\end{array}$

317 Table 6 Technological attributes frequencies by raw materials for the Solutrean sample. Percentages are shown 318 in parentheses.

\begin{tabular}{|c|c|c|c|c|}
\hline & Chert & Quartz & Chalcedony & Total \\
\hline \multicolumn{5}{|l|}{ Blank } \\
\hline CompleteFlake & $4(16.7)$ & $7(33.3)$ & $2(50.0)$ & $13(26.5)$ \\
\hline FlakeFragment & $20(83.3)$ & $14(66.7)$ & $2(50.0)$ & $36(73.5)$ \\
\hline Non_identifiable & $0(0.0)$ & $0(0.0)$ & $0(0.0)$ & $0(0.0)$ \\
\hline \multicolumn{5}{|l|}{ AxisCoincident } \\
\hline No & $15(62.5)$ & $12(57.1)$ & $2(50.0)$ & $29(59.2)$ \\
\hline Yes & $9(37.5)$ & $9(42.9)$ & $2(50.0)$ & $20(40.8)$ \\
\hline \multicolumn{5}{|l|}{ CrossSection } \\
\hline Other & $1(4.2)$ & $1(4.8)$ & $0(0.0)$ & $2(4.1)$ \\
\hline Rectangular & $4(16.7)$ & $3(14.3)$ & $0(0.0)$ & $7(14.3)$ \\
\hline Trapezoidal & $8(33.3)$ & $12(57.1)$ & $3(75.0)$ & $23(46.9)$ \\
\hline Triangular & $11(45.8)$ & $5(23.8)$ & $1(25.0)$ & $17(34.7)$ \\
\hline \multicolumn{5}{|l|}{ SideSection } \\
\hline Elliptical & $3(12.5)$ & $4(19.0)$ & $0(0.0)$ & $7(14.3)$ \\
\hline Irregular & $3(12.5)$ & $1(4.8)$ & $1(25.0)$ & $5(10.2)$ \\
\hline Rectangular & $2(8.3)$ & $4(19.0)$ & $1(25.0)$ & $7(14.3)$ \\
\hline Semi_Circular & $2(8.3)$ & $5(23.8)$ & $0(0.0)$ & $7(14.3)$ \\
\hline Trapezoidal & $9(37.5)$ & $3(14.3)$ & $2(50.0)$ & $14(28.6)$ \\
\hline Triangular & $5(20.8)$ & $4(19.0)$ & $0(0.0)$ & $9(18.4)$ \\
\hline \multicolumn{5}{|l|}{ Profile } \\
\hline Straight & $\begin{array}{l}24 \\
(100.0)\end{array}$ & $21(100.0)$ & $4(100.0)$ & $49(100.0)$ \\
\hline \multicolumn{5}{|l|}{ BlankShape } \\
\hline Biconvex & $0(0.0)$ & $1(4.8)$ & $0(0.0)$ & $1(2.0)$ \\
\hline Circular & $2(8.3)$ & $1(4.8)$ & $0(0.0)$ & $3(6.1)$ \\
\hline Converging & $1(4.2)$ & $3(14.3)$ & $1(25.0)$ & $5(10.2)$ \\
\hline Irregular & $6(25.0)$ & $3(14.3)$ & $1(25.0)$ & $10(20.4)$ \\
\hline Other & $2(8.3)$ & $0(0.0)$ & $0(0.0)$ & $2(4.1)$ \\
\hline Parallel & $13(54.2)$ & $13(61.9)$ & $2(50.0)$ & $28(57.1)$ \\
\hline \multicolumn{5}{|l|}{ Cortex } \\
\hline$<25 \%$ & $1(4.2)$ & $0(0.0)$ & $0(0.0)$ & $1(2.0)$ \\
\hline$>95 \%$ & $1(4.2)$ & $1(4.8)$ & $0(0.0)$ & $2(4.1)$ \\
\hline
\end{tabular}




$\begin{array}{lllll}25-50 \% & 4(16.7) & 0(0.0) & 0(0.0) & 4(8.2) \\ \begin{array}{l}\text { No_Cortex } \\ \text { ButtType }\end{array} & 18(75.0) & 20(95.2) & 4(100.0) & 42(85.7) \\ \text { Absent } & 22(91.7) & 21(100.0) & 4(100.0) & 47(95.9) \\ \begin{array}{l}\text { Flat } \\ \text { Retouch }\end{array} & 2(8.3) & 0(0.0) & 0(0.0) & 2(4.1) \\ \text { No } & 23(95.8) & 21(100.0) & 4(100.0) & 48(98.0) \\ \text { Yes } & 1(4.2) & 0(0.0) & 0(0.0) & 1(2.0) \\ \begin{array}{l}\text { Fire } \\ \text { Burnt }\end{array} & 1(4.2) & 0(0.0) & 1(25.0) & 2(4.1) \\ \text { No_Traces } & 23(95.8) & 21(100.0) & 3(75.0) & 47(95.9)\end{array}$

Table 7 Technological attributes frequencies by raw materials for the Magdalenian sample. Percentages are shown in parentheses.

\begin{tabular}{|c|c|c|c|}
\hline & Chert & Quartz & Total \\
\hline \multicolumn{4}{|l|}{ Blank } \\
\hline FlakeFragment & $2(100.0)$ & $3(100.0)$ & $5(100.0)$ \\
\hline Non_identifiable & $0(0.0)$ & $0(0.0)$ & $0(0.0)$ \\
\hline \multicolumn{4}{|l|}{ AxisCoincident } \\
\hline No & $0(0.0)$ & $2(66.7)$ & $2(40.0)$ \\
\hline Yes & $2(100.0)$ & $1(33.3)$ & $3(60.0)$ \\
\hline \multicolumn{4}{|l|}{ CrossSection } \\
\hline Rectangular & $0(0.0)$ & $2(66.7)$ & $2(40.0)$ \\
\hline Trapezoidal & $1(50.0)$ & $0(0.0)$ & $1(20.0)$ \\
\hline Triangular & $1(50.0)$ & $1(33.3)$ & $2(40.0)$ \\
\hline \multicolumn{4}{|l|}{ SideSection } \\
\hline Elliptical & $1(50.0)$ & $0(0.0)$ & $1(20.0)$ \\
\hline Semi_Circular & $0(0.0)$ & $1(33.3)$ & $1(20.0)$ \\
\hline Trapezoidal & $0(0.0)$ & $1(33.3)$ & $1(20.0)$ \\
\hline Triangular & $1(50.0)$ & $1(33.3)$ & $2(40.0)$ \\
\hline \multicolumn{4}{|l|}{ Profile } \\
\hline Straight & $2(100.0)$ & $3(100.0)$ & $5(100.0)$ \\
\hline \multicolumn{4}{|l|}{ BlankShape } \\
\hline Circular & $0(0.0)$ & $1(33.3)$ & $1(20.0)$ \\
\hline Converging & $0(0.0)$ & $1(33.3)$ & $1(20.0)$ \\
\hline Irregular & $1(50.0)$ & $0(0.0)$ & $1(20.0)$ \\
\hline Parallel & $1(50.0)$ & $1(33.3)$ & $2(40.0)$ \\
\hline \multicolumn{4}{|l|}{ Cortex } \\
\hline No_Cortex & $2(100.0)$ & $3(100.0)$ & $5(100.0)$ \\
\hline \multicolumn{4}{|l|}{ ButtType } \\
\hline Absent & $2(100.0)$ & $3(100.0)$ & $5(100.0)$ \\
\hline Retouch & & & \\
\hline
\end{tabular}




$\begin{array}{llll}\text { No } & 2(100.0) & 3(100.0) & 5(100.0) \\ \text { Fire } & & & \\ \text { No_Traces } & 2(100.0) & 3(100.0) & 5(100.0)\end{array}$

As in other classes of stone tools, scaled pieces' metric attributes are impacted by both the initial blank size as well as by the intensity of their use. Specifically, because some scaled pieces are used in multiple axes, direct comparisons for length and width of the typological axes cannot be straightforwardly performed. Since the majority of the analyzed pieces presented a rectangular outline, we use the area of a rectangle (i.e. typological Length $\mathrm{x}$ Width) as an approximation for the overall dimensions of the artifacts. Area calculations revealed a maximum of $1082.03 \mathrm{~mm}^{2}$ and a minimum of $94.86 \mathrm{~mm}^{2}$. For thickness, the maximum is $28.81 \mathrm{~mm}$ and the minimum is $2.79 \mathrm{~mm}$. In general, mean values tend to be similar between raw materials, with some differences occurring within the Proto-Solutrean and Magdalenian assemblages, most certainly as a result of the small samples analyzed for each of these periods (Figure 2). Across technocomplexes, however, no significant statistical differences were detected when using an ANOVA test for both Area $(F(3,132)=1.1761119, p=0.3213952, d=0.1634926)$, and Thickness $(F(3$, $134)=1.6205801, p=0.1875711, d=0.1904774)$.

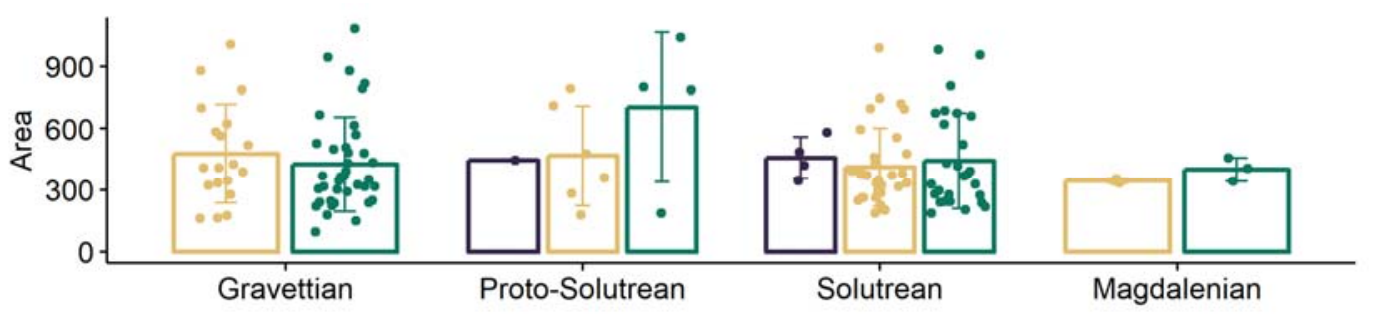

RawMaterial

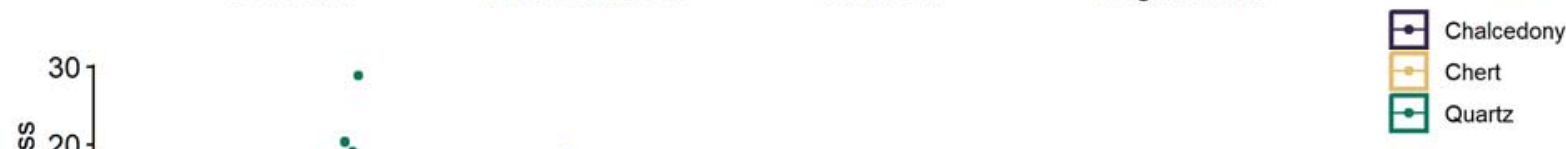

Figure 2 Barplots of means for Area (Length $x$ Width) and Thickness of scaled pieces, by raw material and across the four chronological phases. Error bars represent standard deviations.

The patterns of use and rotation of damaged platforms seem to be the same across all chronologies. In every assemblage quartz pieces were exclusively used in one single axis, exhibiting only two damaged platforms. On the other end, a small number of chert and chalcedony artifacts $(n=12)$ exhibit multiple functional axes, with three or four damaged platforms (Figure 3). This seems to indicate different strategies of curation for coarse (quartz) 
the first used axis becomes too small and/or the edges get useless for that specific activity. However, when plotted against metric data (Figure 4), results for the Area variable reveal that pieces with four damaged platforms are among the largest in all assemblages and that there is not a visible difference between the thicknesses of the pieces comprising each group. This seems to attest that the use of several axes in the same piece is not correlated with curation occurring in later phases of artifact use, but instead to a probable difference in raw material performance.
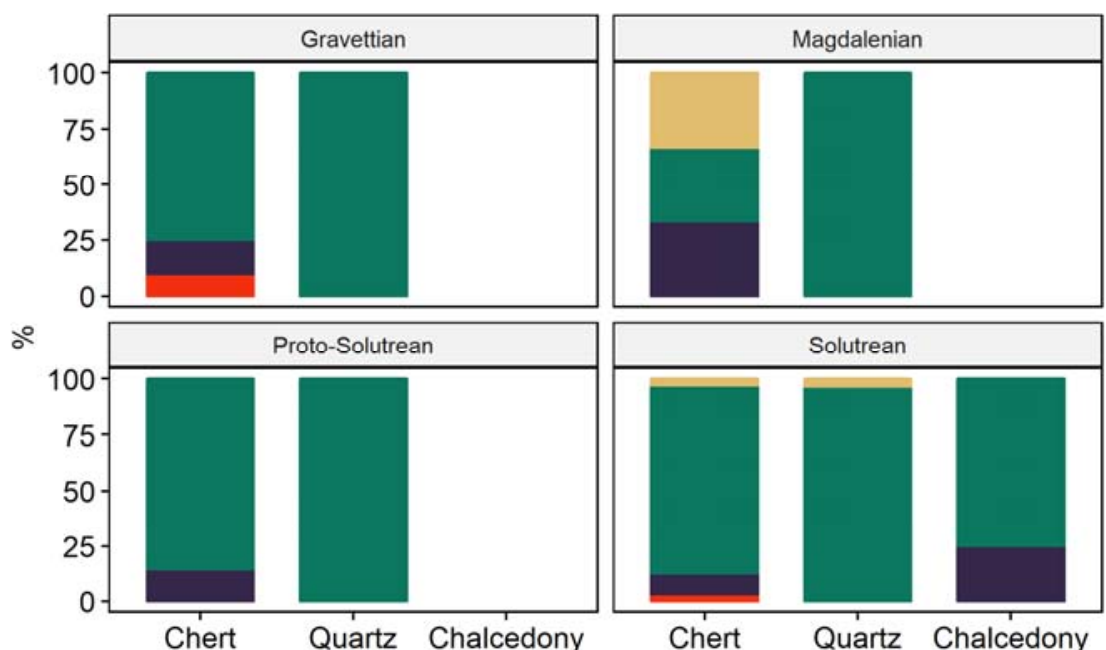

Number of Damaged Platforms
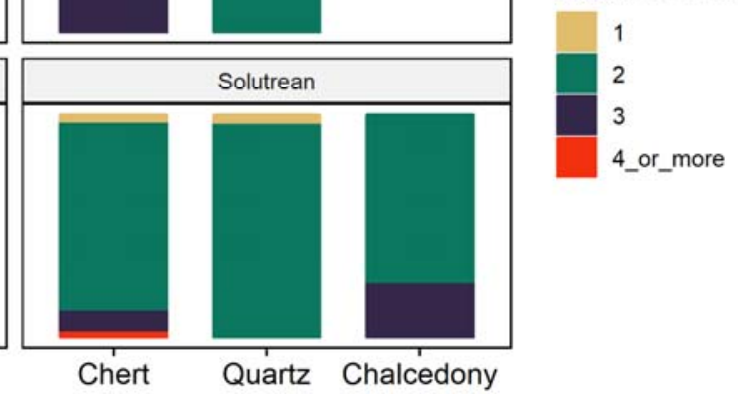

Figure 3 Number of damaged platforms by raw material and chronology.

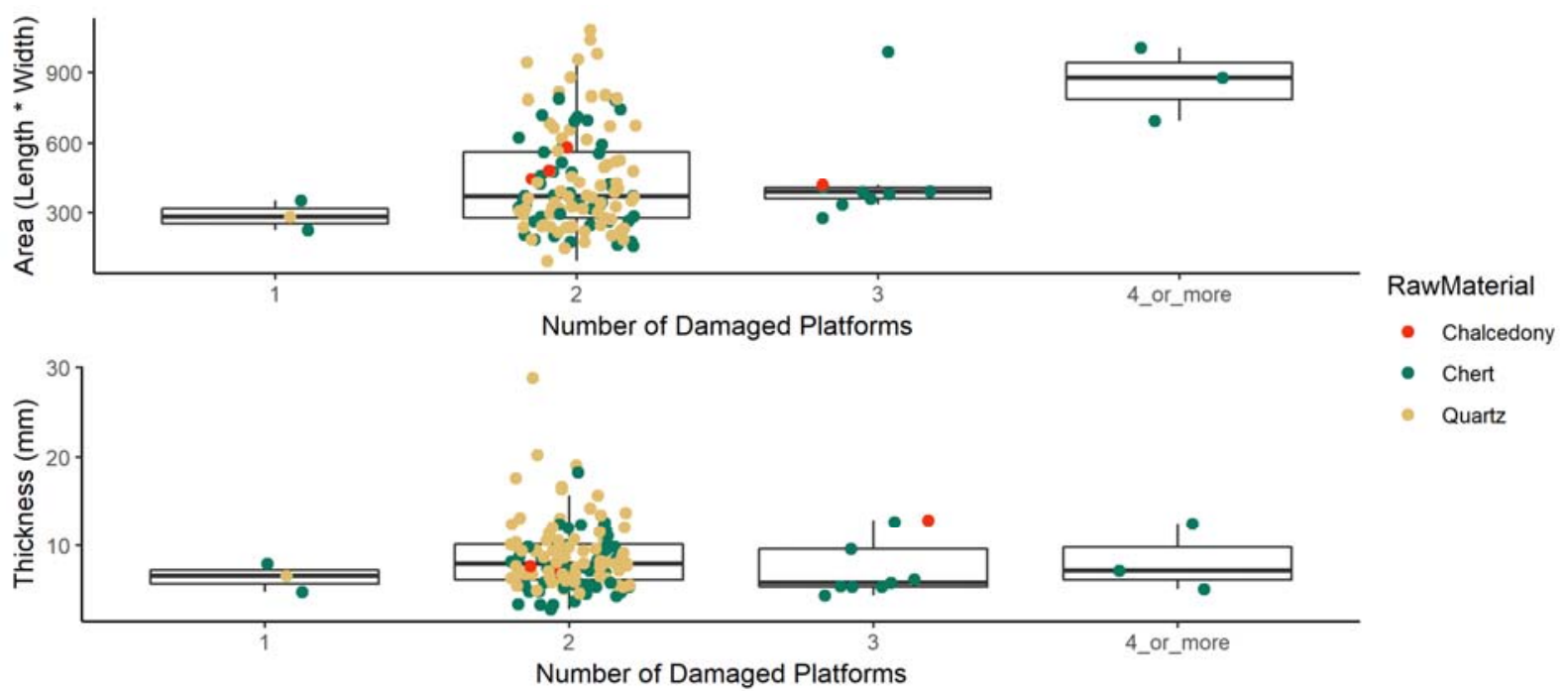

Figure 4 Boxplot of Area (Length $x$ Width) and Thickness distribution for each raw material. 
With few exceptions, most of the morpho-functional attributes show a fairly high degree of variability. Similarly to what was registered for the technological attributes, most of the differences occur between raw materials rather than between chronologies. For this reason, the results presented below focus only on overall and between raw materials variability. Figure 5 shows the relative frequencies of all qualitative variables recorded for each damaged platform. To simplify representation, and to avoid wrong comparisons between hammered and active platforms, opposed damaged platforms were grouped into pairwise categories. When present, the category 'Other' represents the cluster of attributes which frequency was less than $10 \%$ within each variable.

In three (Scar Arrangement, Scar Extension, and Edge Delineation) of the six represented variables, the category 'Other' is one of the most frequent (above 35\%) for both quartz and chert, revealing a very high variability for the combination of attributes within each variable. A chisquare test with modified alpha level (Bonferroni correction) to adjust for multiple testing and reduce type-I error, shows significant differences in the quartz and chert Scar Arrangement categories $\left(X^{2}[4, N=127]=22.94, p=<0.001\right.$, phi $\left.=0.43\right)$, and in Scar Faciality categories $\left(X^{2}\right.$ $[2, N=127]=11.94, p=0.003, p h i=0.31)$. The effect size statistic (Phi) suggests, however, a medium practical significance for both variables.

For quartz artifacts, the most common patterns are the combination of central/total scar distributions, both platforms with angles wider than $45^{\circ}$, and a combination of either unifacial/unifacial or unifacial/bifacial scar distribution. Chert pieces, on the other hand, more typically present opposed platforms with damage occupying the whole platform width, and a weaker presence of unifacial/unifacial scar edge facial distribution. Still, with exception of Angle and Scar Facial Distribution, the overall trend for the morpho-functional variables is one of high variability, with a very large set of combinations appearing at very low frequencies.

A

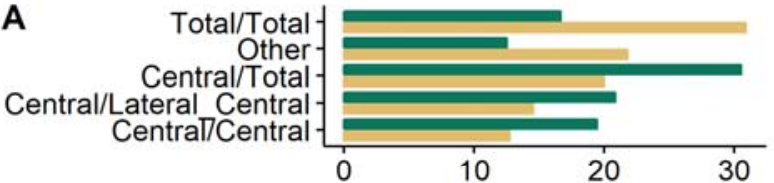

C

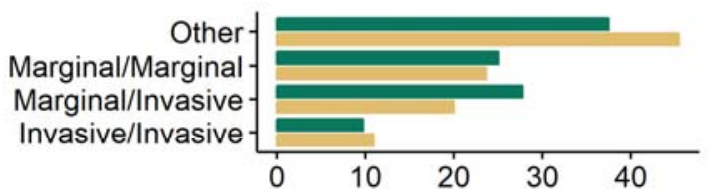

E

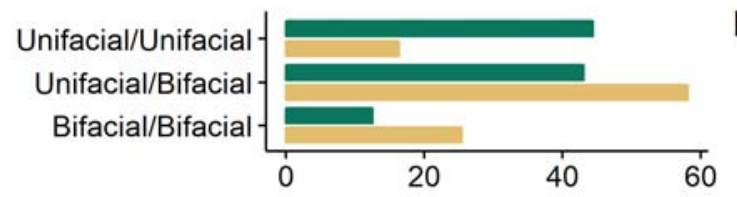

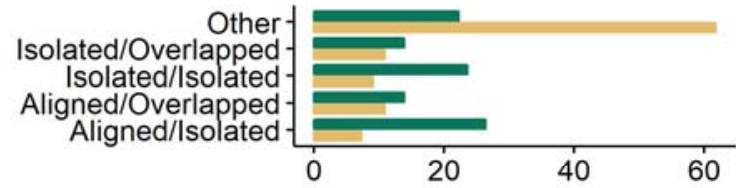

D

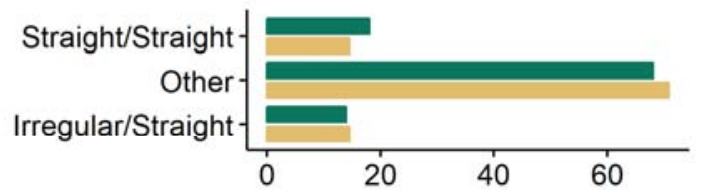

$\mathbf{F}$

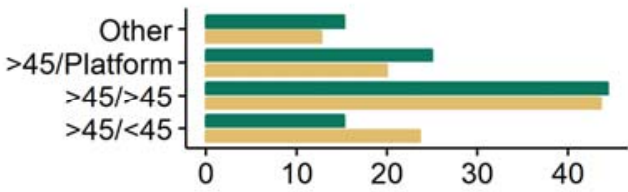

Chert

Quartz

Figure 5 Frequency of morphological attributes for each raw material. Opposed damaged platforms were grouped so that each artifact was only counted once and to avoid wrong comparisons between active and hammered platforms. A - Distribution of damage; $B$ - Arrangement of scars; $C$ - Extension of scars; $D$ Delineation of damaged platforms; $E$ - Facial distribution of scars; $F$ - Angle of damaged platforms. 
391 To identify possible patterns of association among the qualitative variables used in our analysis, 392 a Multiple Correspondence Analysis (MCA) was performed. In this analysis, raw material was 393 used as a qualitative supplementary variable.

394 The first two dimensions of the MCA express $20.92 \%$ of the total dataset inertia, meaning that only that percentage of the total variability is explained by the plane combining the first two dimensions. An inspection of the screeplot presented in Figure 6 suggests restricting the analysis to the description of the first 4 dimensions. These dimensions present an amount of inertia slightly greater than that obtained by the 0.95 -quantile of random distributions $(37.74 \%$ against $34.37 \%)$. Still, it is a rather small percentage, somehow attesting the high variability suggested by our interpretation of Figure 5, and suggesting that patterns identified by previous studies (e.g. de la Peña 2015b, 2011), in which certain combinations of attributes were used to discriminate 403 scaled pieces functionalities, are difficult to apply to the assemblage used in this study.

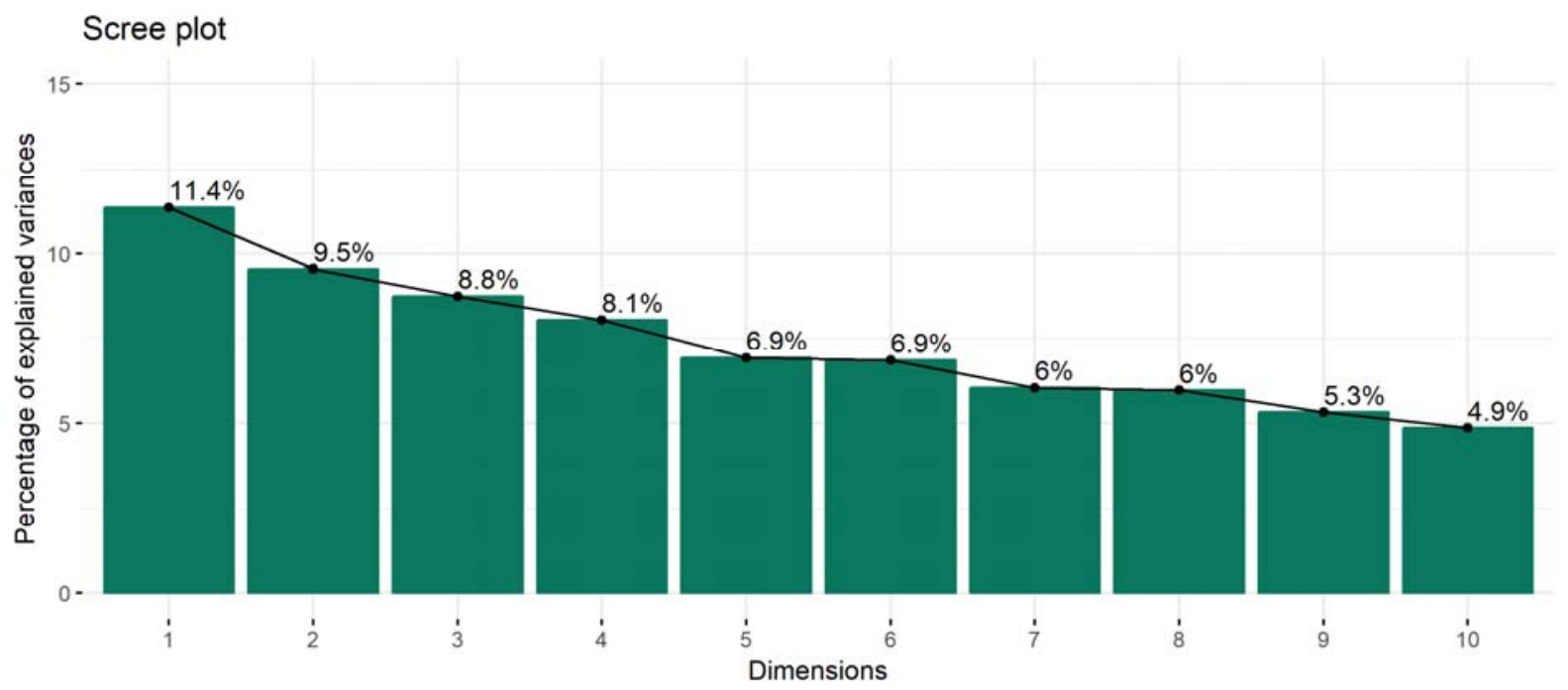

Figure 6 Multiple Correspondence Analysis screeplot.

\section{Discussion and conclusions}

407 Bipolar technology clearly had an important role on the adaptive systems of the first modern 408 humans in Western Iberia, as well as in other European regions (see e.g. Villa et al. 2018; de la 409 Peña 2011; Sano 2012; Zilhão 1997). In Europe, there is a considerable rise in the use of bipolar technologies after the Middle to Upper Paleolithic transition, and some authors consider scaled pieces as one of the most common lithic morphotypes in European Upper Paleolithic assemblages (de la Peña 2011). A rise in bipolar technologies cannot be dissociated from the diverse set of factors that made Anatomically Modern Humans thrive. Changes in mobility patterns (Shott and Tostevin 2015), or the development of a "generalist specialist" ecological approach (Roberts and Stewart 2018), with particular emphasis on the diversification and intensification of resources use, are among some of those traits. It is in the context of this latter 
point that bipolar technology may have played a major role. In Vale Boi, since the earliest occupations at c. $32 \mathrm{ka}$ cal BP, scaled pieces show up in the archaeological record connected to evidence related to an intensification and diversification of resource exploration, particularly the aforementioned grease/marrow obtention techniques. These have been shown by the constant presence of impact fractures in ungulate bones, low percentage of bone areas related to higher amounts of grease, and the presence of red deer bone fragments from bones with considerably higher marrow and grease contents (Manne 2010, 2014; Manne and Bicho 2009; Manne et al. 2012). Other indicators are both the constant presence of thermally altered quartz fragments that might be linked to stone boiling activities, and a large number of greywacke slabs with impact marks revealing their use as anvils (Cascalheira et al. 2017). For carcass processing and bone marrow extraction, the use of scaled pieces would allow for a better control of bone fracture. In fact, this should be significantly better than using a hard hammer directly on the bone, since the latter technique may either over fracture the bone or even crush it due to the lack of precision. The use of a wedge for these activities provides more control, avoiding complete crushing of the bone, making it much easier to cleanly extract bone marrow.

In addition, scaled pieces in Vale Boi may also be associated to bone tool production, given that Vale Boi is one of the Portuguese Upper Paleolithic sites with significant evidence for onsite production and use of bone tools (Évora 2013). According to both Leblanc (1992) and Shott (1999) wedges are needed to work bone, antler, and wood, and stone wedges are preferable than other types of material. For hunter-gatherers, these artifacts would provide multifunctionality from a single piece that could be continuously used until losing their optimal morphological characteristics.

Importantly, our results show that the use of scale pieces at Vale Boi reveals techno-functional patterns that seem to stay fairly similar across all Upper Paleolithic horizons. One relevant trend is the fact that while quartz pieces were only explored in a single axis, chert pieces were, sometimes, explored in multiple axes. One possible reason for these patterns might be the fact that quartz would be more easily available than chert, and thus tool economy would have been different between both materials. Another possibility for this is the difference in the physical properties of each raw material. While with quartz it may be possible to continuously use a single axis in a piece, reducing it in only one axis without losing its efficiency, with chert it may be necessary to rotate it more often in order to continue obtaining usable edges. On the other hand, the higher number of axis could simply suggest that chert was differently managed and economized. Nevertheless, the simple fact that most of the pieces with multiple axes are on average larger than the rest, suggests that this hypothesis is likely incorrect. From an economic standpoint, the ideal would be to continuously use the same piece without any risk of loss of the features that made it ideal for this kind of use. Throughout the use of these pieces, they suffer successive violent blows, even the platform that rests on a surface suffers some sort of heavy impact. In this specific case, we argue that there is little to no control on how the piece's features change over its lifetime use.

Several researchers argued that scaled pieces were used as cores for the extraction of chips or small bladelets (e.g. Carvalho 1998; de la Peña 2011; LeBlanc 1992; Shott 1989, 1999; Zilhão 1997). Based on our data we find that this concept does not seem to fit in Vale Boi. First, with the single exception of the early Gravettian (during which very small backed bladelets are present - see Marreiros et al. (2018)), the site's technology shows no evidence of manufacture or use of tools with such small dimensions as the ones recorded from the scars of scaled pieces (5-8 
$\mathrm{mm}$ ). Second, although the most common interpretation is that these chips/bladelets would be inserted in composite throwing tools, there is no evidence of bone or antler tools with grooves that might be used for the insertion of stone implements even though Vale Boi has a very rich assemblage of organic tools (Évora 2013). However, we still do not discard the hypothesis that these may have been made from perishable organic materials. Third, although previous ethnographic studies (e.g. Flenniken 1981; Shott 1989) support the use of small flakes, bladelets, and chips for these types of implements and other activities such as scraping, boring and cutting, we currently have no use-wear data that can support this hypothesis at the site. Finally, as previously mentioned, Vale Boi stone tool technological analyses revealed that every phase of the chaîne operatoire is present, which means that knapping was mostly occurring at the site, which is attested by the high number of chips found. Considering that most knapping activities originate chipage, the need of a specific tool for the sole purpose of extracting them does not seem viable. By putting all these factors in context, the hypothesis that these pieces were used for carcass processing, bone marrow extracting (Manne et al. 2012) and other similar activities, such as working hard, organic materials with the goal of producing tools seems, thus far, to be the most reasonable interpretation. The use of scaled pieces as wedges would allow for further enhancement of the effectiveness of these activities and has been identified in modern human occupations all over the world (Igreja and Porraz 2013; Langejans 2012; LeBlanc 1992; Sano 2012; Shott 1989). In fact, this technique would be extremely useful in periods of greater environmental stress and in periods when communities needed higher mobility. Despite this, we do not discard the possibility that some scaled pieces might have been used for bipolar reduction strategies. In addition to the amount of stone anvils at the site, bipolar cores are also present across all techno-complexes (Cascalheira 2010; Marreiros 2009). There may even be the case that blanks from bipolar cores were transformed into scaled pieces by using them for further bipolar or wedging activities. Unfortunately, due to the nature of the damage present in scaled pieces, this is a very hard point to prove. Still, open hypotheses clearly attest the value and versatility of bipolar technologies for early modern human groups in the region.

Taking this into consideration, in Table 8 we present current data on Upper Paleolithic bipolar technology in Portugal. It is important to note that aside from Vale Boi, all scaled pieces and bipolar cores counts in this table were made according to each author's typological definitions and classifications, and not the ones we propose for this paper. Although the number of scaled pieces and bipolar cores is considerably low in most of the sites, a significant number of loci present some kind of bipolar technology evidence. Moreover, it is clear a discrepancy when comparing the presence of scaled pieces versus bipolar cores, the latter being well underrepresented than the first. It is also clear that scaled pieces show on average a higher representation in Vale Boi's assemblages than on most other sites. Further, of the three bipolar cores in all sites, two of these come from Vale Boi. While currently there are no definitive data on the representation of scaled pieces within the retouched tool assemblage of the Slope area, it is fairly safe to assume that it should be a particularly high value.

Table 8 Frequencies of scaled pieces and bipolar cores in Portuguese Upper Paleolithic sites.

\begin{tabular}{llrlrrrl} 
& & $\begin{array}{r}\text { Scaled } \\
\text { Pieces } \\
\text { Chronology }\end{array}$ & $\begin{array}{l}\text { Scaled } \\
\text { Pieces } \\
(\%)\end{array}$ & $\begin{array}{r}\text { Bipolar } \\
\text { Cores (N) }\end{array}$ & $\begin{array}{r}\text { Bipolar } \\
\text { Cores (\%) }\end{array}$ & $\begin{array}{r}\text { Total } \\
(\%)\end{array}$ & Source \\
\hline Gravettian & Casal do Felipe & 12 & 5.91 & 0 & 0.0 & 2.33 & Zilhão (1997)
\end{tabular}




\begin{tabular}{|c|c|c|c|c|c|c|c|}
\hline Gravettian & CPM III & 1 & 0.81 & 0 & 0.0 & 0.19 & Zilhão (1997) \\
\hline Gravettian & Fonte Santa & 105 & 12.49 & 0 & 0.0 & 20.43 & Zilhão (1997) \\
\hline Gravettian & Gato Preto & 3 & 3.13 & 0 & 0.0 & 0.58 & Zilhão (1997) \\
\hline Gravettian & $\begin{array}{l}\text { Gruta do } \\
\text { Caldeirão }\end{array}$ & 1 & 11.11 & 0 & 0.0 & 0.00 & Zilhão (1997) \\
\hline Gravettian & $\begin{array}{l}\text { Salto do Boi - } \\
\text { Cardina I }\end{array}$ & 1 & 2.7 & 0 & 0.0 & 0.19 & $\begin{array}{l}\text { Zilhão et al. } \\
\text { (1995) }\end{array}$ \\
\hline Gravettian & $\begin{array}{l}\text { Vale Boi - } \\
\text { Terrace }\end{array}$ & 12 & 37.5 & 1 & 0.0 & 2.33 & $\begin{array}{l}\text { Cascalheira } \\
(2009) \text {; Marreiros } \\
(2009)\end{array}$ \\
\hline Gravettian & Vale Boi - Slope & 59 & NA & 0 & 0.0 & 11.48 & Horta, 2016 \\
\hline Gravettian & $\begin{array}{l}\text { Vale Comprido - } \\
\text { Barraca }\end{array}$ & 10 & 2.6 & 0 & 0.0 & 1.95 & Zilhão (1997) \\
\hline Gravettian & $\begin{array}{l}\text { Vales da } \\
\text { Senhora da Luz }\end{array}$ & 1 & 0.32 & 0 & 0.0 & 0.19 & Zilhão (1997) \\
\hline $\begin{array}{l}\text { Proto- } \\
\text { Solutrean }\end{array}$ & $\begin{array}{l}\text { Terra do José } \\
\text { Pereira }\end{array}$ & 4 & 1.91 & 0 & 0.0 & 0.78 & Zilhão (1997) \\
\hline $\begin{array}{l}\text { Proto- } \\
\text { Solutrean }\end{array}$ & $\begin{array}{l}\text { Terra do Manuel } \\
(1940-1942)\end{array}$ & 9 & 1.03 & 0 & 0.0 & 1.75 & Zilhão (1997) \\
\hline $\begin{array}{l}\text { Proto- } \\
\text { Solutrean }\end{array}$ & $\begin{array}{l}\text { Terra do Manuel } \\
(1988-1989)\end{array}$ & 1 & 2.13 & 0 & 0.0 & 0.19 & Zilhão (1997) \\
\hline $\begin{array}{l}\text { Proto- } \\
\text { Solutrean }\end{array}$ & Vale Boi Slope & 13 & $?$ & 0 & 0.0 & 2.53 & Horta (2016) \\
\hline $\begin{array}{l}\text { Proto- } \\
\text { Solutrean }\end{array}$ & $\begin{array}{l}\text { Vale Comprido - } \\
\text { Encosta }\end{array}$ & 9 & 0.9 & 0 & 0.0 & 1.75 & Zilhão (1997) \\
\hline Solutrean & Casal do Cepo & 6 & 1.43 & 0 & 0.0 & 1.17 & Zilhão (1997) \\
\hline Solutrean & $\begin{array}{l}\text { Gruta de } \\
\text { Salemas II }\end{array}$ & 1 & 1.69 & 0 & 0.0 & 0.19 & Zilhão (1997) \\
\hline Solutrean & $\begin{array}{l}\text { Gruta de } \\
\text { Salemas UP } \\
\text { Mixed }\end{array}$ & 1 & 1.16 & 0 & 0.0 & 0.19 & Zilhão (1997) \\
\hline Solutrean & Lagar Velho 09 & 1 & 3.45 & 0 & 0.0 & 0.19 & Zilhão (1997) \\
\hline Solutrean & Vale Almoinha & 26 & 5.9 & 0 & 0.0 & 5.05 & Zilhão (1997) \\
\hline Solutrean & $\begin{array}{l}\text { Vale Boi } \\
\text { Rockshelter }\end{array}$ & 24 & 11.7 & 1 & 2.3 & 4.67 & Marreiros (2009) \\
\hline Solutrean & $\begin{array}{l}\text { Vale Boi } \\
\text { Terrace }\end{array}$ & 5 & 13.51 & 0 & 0.0 & 0.97 & Cascalheira (2009) \\
\hline Solutrean & Vale Boi Slope & 66 & NA & 0 & 0.0 & 12.84 & Horta (2016) \\
\hline Magdalenian & Areeiro I & 8 & 4 & 0 & 0.0 & 1.56 & Bicho (2000) \\
\hline Magdalenian & $\begin{array}{l}\text { Areeiro III área } \\
1\end{array}$ & 16 & 2.9 & 0 & 0.0 & 3.11 & Bicho (2000) \\
\hline Magdalenian & $\begin{array}{l}\text { Areeiro III área } \\
2\end{array}$ & 10 & 2.9 & 0 & 0.0 & 1.95 & Bicho (2000) \\
\hline Magdalenian & Areeiro Teste & 6 & 1.4 & 0 & 0.0 & 1.17 & Bicho (2000) \\
\hline Magdalenian & Carneira I & 2 & 0.35 & 0 & 0.0 & 0.39 & Zilhão (1997) \\
\hline Magdalenian & Carneira II & 17 & 9.9 & 1 & 4.3 & 3.31 & Bicho (2000) \\
\hline Magdalenian & Cerrado Novo & 5 & 0.93 & 0 & 0.0 & 0.97 & Bicho (2000) \\
\hline
\end{tabular}




\begin{tabular}{|c|c|c|c|c|c|c|c|}
\hline Magdalenian & CPM I Inferior & 1 & 0.5 & 0 & 0.0 & 0.19 & Zilhão (1997) \\
\hline Magdalenian & CPM I Superior & 18 & 1.2 & 0 & 0.0 & 3.50 & Bicho (2000) \\
\hline Magdalenian & CPM II Middle & 4 & 3.4 & 0 & 0.0 & 0.78 & Bicho (2000) \\
\hline Magdalenian & CPM II Superior & 2 & 1.1 & 0 & 0.0 & 0.39 & Zilhão (1997) \\
\hline Magdalenian & CPM IIIS & 5 & 1.3 & 0 & 0.0 & 0.97 & Bicho (2000) \\
\hline Magdalenian & $\begin{array}{l}\text { CPM III } \\
\text { Superior }\end{array}$ & 2 & 1.1 & 0 & 0.0 & 0.39 & Bicho (2000) \\
\hline Magdalenian & CPM V & 2 & 1.3 & 0 & 0.0 & 0.39 & Bicho (2000) \\
\hline Magdalenian & $\begin{array}{l}\text { Olival da } \\
\text { Carneira }\end{array}$ & 3 & 1.11 & 0 & 0.0 & 0.58 & Zilhão (1997) \\
\hline Magdalenian & $\begin{array}{l}\text { Pinhal da } \\
\text { Carneira }\end{array}$ & 2 & 1 & 0 & 0.0 & 0.39 & Bicho (2000) \\
\hline Magdalenian & Quinta da Barca & 9 & 10.23 & 0 & 0.0 & 1.75 & Bicho (2000) \\
\hline Magdalenian & $\begin{array}{l}\text { Quinta da Barca } \\
\text { Sul }\end{array}$ & 22 & 42.31 & 0 & 0.0 & 4.28 & Bicho (2000) \\
\hline Magdalenian & $\begin{array}{l}\text { Quinta da } \\
\text { Granja }\end{array}$ & 3 & 13.04 & 0 & 0.0 & 0.58 & Bicho (2000) \\
\hline Magdalenian & Rossio do Cabo & 1 & 1.14 & 0 & 0.0 & 0.19 & Zilhão (1997) \\
\hline Magdalenian & Vale da Mata & 6 & 0.45 & 0 & 0.0 & 1.17 & Zilhão (1997) \\
\hline
\end{tabular}

Bipolar technology is quite common in Upper Paleolithic contexts of Western Iberia, but current interpretations are based on empirical observations, rather than on more solid analytical evidence. This, of course, stems in part from the lack of dedicated studies on bipolar technology in the region, an issue that can be also argued to be true for all of the European Upper Paleolithic. We argue that all factors mentioned in this study must be considered while interpreting each site in this region. While in Vale Boi there is clear evidence that the use of these artifacts would not be primarily for bipolar knapping, in other sites the picture may be 511 different.

As our results show, the low presence of bipolar cores is quite evident in these sites, while scaled pieces are more often present. It can also be argued that the number of pieces in the overall picture is also low, although presenting an accurate picture for each site since most of these sites 515 have been extensively studied.

516 Higher degrees of representation of scaled pieces in sites can be originated by factors such as site 517 function, but also by cultural patterns. Regarding site functionality, if we look at the loci with 518 higher counts of scaled pieces (Vale Boi's Terrace and Slope and Fonte Santa), all are open-air 519 residential sites. One example outside of this region is the Magdalenian site of Gönnersdorf in 520 Southwestern Germany, where according to Sano (2012) scaled pieces were the second most 521 frequent tool types within the site's retouched tools assemblage (257 from a total of 1501 522 utensils, corresponding to c. 17,12\%). This frequency is as high as both Vale Boi's and Fonte 523 Santa's, and like both of these sites Gönnersdorf is an open-air residential site. However, these 524 data can be misleading, as Casal do Felipe (5,91\%), Terra do Manuel 1940-42 (1,03\%), Terra do 525 Manuel 1988-89 (2,13\%) and Vale Comprido - Encosta (0,9\%) are also open-air multifunctional sites with much smaller representations of scaled pieces. 
It seems reasonable that scaled pieces should be linked mostly with residential sites since the activities for which they are applied are conducted in a residential scenario rather than a hunting station, quarry, workshop or temporary shelter. While we cannot fully discard the fact that scaled pieces can be used as a single representation of site functionality, they can be a tool for such ends, as argued by Jeske and Sterner-Miller (2015). We, thus, argue that in this region, bipolar technology in the Upper Paleolithic may be also linked to cultural traditions rather than just simply functional ones. By considering that most sites aforementioned show similarities from a functional, chronological, faunal, floral and climate standpoints, there is no clear reason for the presence of different relative numbers of scaled pieces at each site other than a combination of both cultural and functional patterns.

\section{Acknowledgments}

We would like to thank a diversity of institutions that provided funding to the work in Vale Boi in the last decade. These are Fundação para a Ciência e Tecnologia (Grants PTDC/HAH/64184/2006, SFRH/BD/65527/2009 and PTDC/HIS-ARQ/117540/2010), National Geographic Society (Grant \#8045-06), and Wenner-Gren Foundation for Anthropological Research (Grant \#8290). Thanks also to the three anonymous reviewers for their valuable comments that helped to improve the content of the paper.

\section{References}

Almeida, F. (2000). The terminal Gravettian of Portuguese estremadura: Technological variability of the lithic industries (PhD Thesis). Southern Methodist University.

Andrefsky Jr, W. (2005). Lithics: Macroscopic approaches to analysis (2nd edition.). Cambridge: Cambridge University Press.

Bader, G. D., Will, M., \& Conard, N. J. (2015). The lithic technology of Holley Shelter, KwaZulu-Natal, and its place within the MSA of southern Africa. The South African Archaeological Bulletin, 149-165.

Bardon, L., \& Bouyssonie, A. (1906). Outils écaillés par percussion à la Coumba del Bouitou (Corrèze). Revue de l'École d'Anthropologie, 16, 170-175.

Belmiro, J., Cascalheira, J., \& Bicho, N. (2017). O ínicio do Último Máximo Glacial no Sul de Portugal: Novos dados a partir do sítio arqueológico de Vale Boi. In Arqueologia em Portugal 2017: Estado da Questão (pp. 375-384). Lisbon.

Bicho, N. (2000). Technological change in the final Upper Paleolithic of Rio Maior. Tomar: Arkeos, 8.

Bicho, N., Cascalheira, J., \& Marreiros, J. (2012). On the (L)Edge: The Case of Vale Boi Rockshelter (Algarve, Southern Portugal). In K. A. Bergsvik \& R. Skeates (Eds.), Caves in Context - The Cultural Significance of Caves and Rockshelters in Europe. Oxbow Books.

Bicho, N. F., Gibaja, J. F., Stiner, M., \& Manne, T. (2010). Le paléolithique supérieur au sud du Portugal : Le site de Vale Boi. L’Anthropologie, 114, 48-67. doi:10.1016/j.anthro.2010.01.002 
Bicho, N., Manne, T., Marreiros, J., Cascalheira, J., Pereira, T., Tátá, F., et al. (2013). The ecodynamics of the first modern humans in Southwestern Iberia: The case of Vale Boi, Portugal. Quaternary International, 318, 102-116. doi:10.1016/j.quaint.2013.06.029

Binford, L. R., \& Quimby, G. I. (1963). Indian Sites and Chipped Stone Materials: In the Northern Lake Michigan Area. Fieldiana. Anthropology, 36(12), 277-307.

Bradtmöller, M., Marreiros, J., Pereira, T., \& Bicho, N. (2016). Lithic technological adaptation within the Gravettian of the Iberian Atlantic region: Results from two case studies. Quaternary International, 406, 3-24.

Brantingham, P. J., Gao, X., Madsen, D. B., Bettinger, R. L., Elston, R. G., Brantingham, P. J., et al. (2004). The Early Upper Paleolithic Beyond Western Europe. University of California Press.

Carvalho, A. F. (1998). Talhe da pedra no Neolítico antigo do maciço calcário das serras d'Aire e Candeeiros Estremadura portuguesa: Um primeiro modelo technológico e tipológico. Colibri.

Cascalheira, J. (2010). Tecnologia lítica do abrigo Solutrense de Vale Boi. Lisbon: UNIARQ.

Cascalheira, J. (2013). A influência mediterrânica nas redes sociais do Solutrense final peninsular (Ph.D. Thesis). Universidade do Algarve, Faro.

Cascalheira, J., \& Bicho, N. (2015). On the Chronological Structure of the Solutrean in Southern Iberia. PLoS One, 10, e0137308. doi:10.1371/journal.pone.0137308

Cascalheira, J., Bicho, N., Manne, T., \& Horta, P. (2017). Cross-scale adaptive behaviors during the Upper Paleolithic in Iberia: The example of Vale Boi (Southwestern Portugal). Quaternary International, 446, 17-30. doi:https://doi.org/10.1016/j.quaint.2017.01.002

Cascalheira, J., Bicho, N., Marreiros, J., Pereira, T., Évora, M., Cortés Sánchez, M., et al. (2012). Vale Boi (Algarve, Portugal) and the Solutrean in Southwestern Iberia. Espacio, Tiempo y Forma, 5, 455-467. doi:10.5944/etf \%0020i.5.5376

Crabtree, D. E. (1972). An introduction to flintworking. Occasional Papers of the Museum, Idaho State University, 28, 1-98.

Debénath, A., \& Dibble, H. L. (1994). Handbook of Paleolithic Typology: Lower and middle paleolithic of Europe (Vol. 1). UPenn Museum of Archaeology.

de la Peña, P. (2011). Sobre la identificación macroscópica de las piezas astilladas: Propuesta experimental. Trabajos de Prehistoria, 68, 79-98. doi:10.3989/tp.2011.11060

de la Peña, P. (2015a). The interpretation of bipolar knapping in African Stone Age studies. Current Anthropology, 56(6), 911-923.

de la Peña, P. (2015b). A qualitative guide to recognize bipolar knapping for flint and quartz. Lithic Technology, 40, 316-331.

de la Peña, P., \& Wadley, L. (2014). New knapping methods in the Howiesons Poort at Sibudu (KwaZulu-Natal, South Africa). Quaternary International, 350, 26-42. 
Diez-Martín, F., Sánchez, P., Domínguez-Rodrigo, M., Mabulla, A., \& Barba, R. (2009). Were Olduvai hominins making butchering tools or battering tools? Analysis of a recently excavated lithic assemblage from BK (Bed II, Olduvai Gorge, Tanzania). Journal of Anthropological Archaeology, 28(3), 274-289.

Évora, M. (2013). Osseous industry and exploitation of animal resources in Southern Iberia during the Upper Palaeolithic. Quaternary International, 318, 33-45. doi:10.1016/j.quaint.2013.09.013

Fischer, A., Hansen, P. V., \& Rasmussen, P. (1984). Macro and micro wear traces on lithic projectile points: Experimental results and prehistoric examples. Journal of Danish Archaeology, 3(1), 19-46.

Flenniken, J. J. (1981). Replicative systems analysis: A model applied to the vein quartz artifacts from the Hoko River site. Washington State University.

Flood, J. (1980). The moth hunters: Aboriginal prehistory of the Australian Alps. Australian Institute of Aboriginal Studies.

Gibaja, J. F., \& Bicho, N. F. (2011). La función de los instrumentos líticos en el asentamiento de Vale Boi (Algarve, Portugal) Estudio del utillaje gravetiense y solutrense. SAGVNTVM. Papeles del Laboratorio de Arqueología de Valencia, 38, 9-21.

Gibaja, J. F., Palomo, A., Bicho, N. F., \& Terradas, X. (2007). Tecnología y función de los "útiles astillados": Programa experimental para contextos prehistóricos de la Península Ibérica. In I Congreso Español de Arqueología experimental en la Península Ibérica (Santander 2005) (pp. 157-164).

Gonçalves, C. M. G. (2012). La variabilité régionale des industries lithiques de la fin du Paléolithique supérieur au Portugal (Ph.D. Thesis). Paris 1.

González-Urquijo, J. E., \& Ibánez-Estévez, J. J. (1994). Metodologia de análisis funcional de instrumentos tallados en silex. Cuadernos de Arqueologia, 14.

Hayden, B. (1980). Confusion in the bipolar world: Bashed pebbles and splintered pieces. Lithic Technology, 9, 2-7.

Hiscock, P. (2015). Dynamics of knapping with bipolar techniques: Modeling transitions and the implications of variability. Lithic Technology, 40, 342-348.

Horta, P. E. G. (2016). Tecnologia e funcionalidade das peças esquiroladas do Paleolítico Superior de Vale Boi, Vila do Bispo (Masters Thesis). Universidade do Algarve.

Igreja, M., \& Porraz, G. (2013). Functional insights into the innovative Early Howiesons Poort technology at Diepkloof Rock Shelter (Western Cape, South Africa). Journal of Archaeological Science, 40(9), 3475-3491.

Inizan, M.-L., Reduron-Ballinger, M., Roche, H., Tixier, J., \& Féblot-Augustins, J. (1999). Technology and terminology of knapped stone. Nanterre: CREP. 
Jeske, R. J., \& Sterner-Miller, K. M. (2015). Microwear analysis of bipolar tools from the Crescent Bay Hunt Club Site (47JE904). Lithic Technology, 40, 366-376.

Kahle, D., \& Wickham, H. (2013). Ggmap: Spatial Visualization with ggplot2. R Journal, 5(1).

Langejans, G. H. J. (2012). Middle Stone Age pièces esquillées from Sibudu Cave, South Africa: An initial micro-residue study. Journal of Archaeological Science, 39, 1694-1704. doi:10.1016/j.jas.2011.12.036

Leaf, G. R. (1979). Variation in the form of bipolar cores. The Plains Anthropologist, 39-50.

LeBlanc, R. (1992). Wedges, pièces esquillées, bipolar cores, and other things: An alternative to Shott's view of bipolar industries. North American Archaeologist, 13, 1-14.

Lucas, G., \& Hays, M. (2004). Les pièces esquillées du site paléolithique du Flageolet I (Dordogne): Outils ou nucléus. In XXV Congrès Préhistorique de France. Approches fonctionnelles en Préhistoire (Nanterre, 2000), Paris (pp. 107-120).

MacDonald, G. F. (1985). Debert: A Paleo-Indian Site in Central Nova Scotia. Persimmon Pr.

Manne, T. (2010). Upper Paleolithic foraging decisions and early economic intensification at Vale Boi, Southwestern Portugal (Ph.D. Thesis). University of Arizona.

Manne, T. (2014). Early Upper Paleolithic bone processing and insights into small-scale storage of fats at Vale Boi, southern Iberia. Journal of Archaeological Science, 43, 111-123. doi:10.1016/j.jas.2013.12.003

Manne, T., \& Bicho, N. (2009). Vale Boi: Rendering new understandings of resource intensification \& diversification in southwestern Iberia. Before Farming, 2009, 1-21.

Manne, T., Cascalheira, J., Évora, M., Marreiros, J., \& Bicho, N. (2012). Intensive subsistence practices at Vale Boi, an Upper Paleolithic site in southwestern Portugal. Quaternary International, 264, 83-99. doi:10.1016/j.quaint.2012.02.026

Marreiros, J., \& Bicho, N. (2013). Lithic technology variability and human ecodynamics during the Early Gravettian of Southern Iberian Peninsula. Quaternary International, 318, 90-101. doi:10.1016/j.quaint.2013.05.008

Marreiros, J., Bicho, N., Gibaja, J., Pereira, T., \& Cascalheira, J. (2015). Lithic technology from the Gravettian of Vale Boi: New insights into Early Upper Paleolithic human behavior in Southern Iberian Peninsula. Quaternary International, 359360, 479-498. doi:http://dx.doi.org/10.1016/j.quaint.2014.06.074

Marreiros, J., Cascalheira, J., \& Bicho, N. (2012). Flake technology from the early Gravettian of Vale Boi (Portugal). Flakes not Blades: The Role of Flake Production at the Onset of the Upper Palaeolithic in Europe. Wissenschaftliche Schriften des Neanderthal Museums, 5, 11-23.

Marreiros, J., Gibaja, J., \& Bicho, N. (2018). Lithic use-wear analysis of the Early Gravettian of Vale Boi (Cape St. Vicente, southern Portugal): Insights into human technology and settlement in southwestern Iberia. Archaeological and Anthropological Sciences, 10(3), 631-645. doi:10.1007/s12520-016-0382-4 
Marreiros, J. M. F. (2009). As primeiras comunidades do Homem moderno no Algarve Ocidental: Caracterização paleotecnológica e paleoetnográfica das comunidades gravetenses e proto-solutrenses de Vale Boi (Algarve, Portugal) (Ph.D. Thesis). Universidade do Algarve.

Marwick, B. (2016). Computational Reproducibility in Archaeological Research: Basic Principles and a Case Study of Their Implementation. Journal of Archaeological Method and Theory, 24(2), 424-450. doi:10.1007/s10816-015-9272-9

Marwick, B., Boettiger, C., \& Mullen, L. (2017). Packaging data analytical work reproducibly using R (and friends). The American Statistician, 0-0. doi:10.1080/00031305.2017.1375986

Octobon, C. (1938). Contribution à l'étude des outillages. Ciseaux et pièces esquillées. Bulletin de la Société Préhistorique Française, 25, 409-412.

Pereira, T., Bicho, N., Cascalheira, J., Infantini, L., Marreiros, J., Paixão, E., \& Terradas, X. (2016). Territory and abiotic resources between 33 and 15.6 ka at Vale Boi (SW Portugal). Quaternary International, 412, Part A, 124-134. doi:http://dx.doi.org/10.1016/j.quaint.2015.08.071

R: A language and environment for statistical computing. (2013). Vienna, Austria: R Foundation for Statistical Computing.

Roberts, P., \& Stewart, B. A. (2018). Defining the "generalist specialist" niche for Pleistocene Homo sapiens. Nature Human Behaviour. doi:10.1038/s41562-018-0394-4

Sano, K. (2012). Functional Variability in the Late Upper Palaeolithic of North-Western Europe. Universitätsforschungen zur Prähistorischen Archäologie, 219.

Shott, M. J. (1989). Bipolar industries: Ethnographic evidence and archaeological implications. North American Archaeologist, 10, 1-24.

Shott, M. J. (1999). On bipolar reduction and splintered pieces. North American Archaeologist, 20, 217-238.

Shott, M., \& Tostevin, G. (2015). Diversity under the bipolar umbrella. Lithic Technology, 40, 377-384.

Sonneville-Bordes, D. de, \& Perrot, J. (1956). Lexique typologique du Paléolithique supérieur. Bulletin de la Société Préhistorique Française, 53, 547-559.

Tixier, J. (1963). Typologie de l'Epipaléolithique du Maghreb. Mémoires du Centre de Recherches Anthropologiques, Préhistoriques et Ethnographiques, No 2. Paris: Arts et Métiers Graphiques.

Villa, P., Pollarolo, L., Conforti, J., Marra, F., Biagioni, C., Degano, I., et al. (2018). From Neandertals to modern humans: New data on the Uluzzian. PLOS ONE, 13(5), e0196786. doi:10.1371/journal.pone.0196786

White, J. P. (1968). Fabricators, outils ecailles or scalar cores. Mankind, 6, 658-66.

Wickham, H. (2015). R packages: Organize, test, document, and share your code. Sebastopol, CA: O'Reilly Media, Inc. 
709 Zilhão, J. (1997). O Paleolítico Superior da Estremadura portuguesa. Lisbon: Colibri.

710 Zilhão, J., Aubry, T., Carvalho, A. de, Zambujo, G., \& Almeida, F. (1995). O sítio arqueológico

711 paleolítico do Salto do Boi (Cardina, Santa Comba, Vila Nova de Foz Côa). Trabalhos de

712 Antropologia e Etnologia, 35(4), 471-497. 